\title{
SOUDOBÁ RECEPCE DÍLA JIŘíHO LEVÉHO VE ŠPANĚLSKU A IBEROAMERICE ${ }^{1}$
}

\author{
PETRA MRAČKOVÁ VAVROUŠOVÁ
}

\begin{abstract}
The article aims to present the contemporary reception of the ideas of the Czech translation scholar Jiří Levý in Spain and Latin America. His ideas, formulated in the 1950s, remain perfectly valid till the present day; nevertheless, the fact that Levý wrote in a minor language meant that the international academic community had limited access to his innovative thinking on translation as a decision process, translation as a communication process and the historical perspective of translation. The Czech scholar's concepts did not receive international recognition until 2011 when his principal work, The Art of Translation (1963), was translated into English. Even before, however, the translation studies community in Spanish and Portuguese speaking countries did read about Levýs thinking, using the German translation (1969). Surprisingly, the reception of his works in that part of the world has not been as limited as one would think and Levý has his admirers who have been disseminating his ideas in their respective areas (Vega in Spanish and Neckel in Portuguese). Besides, translation studies journals in Latin America have published monothematic issues appreciating the works of the Czech translation scholar (Brazil, Scientia Traductionis, 2012; Colombia, Mutatis Mutandis, 2016). Of equal importance are the Spanish anthology Jiří Levý: una concepción (re)descubierta (2013), comprising his most representative texts collected and translated by Jana Králová and Miguel Cuenca, as well as a commented Portuguese translation of the first part of his principal work done by Filipe Neckel which forms part of his doctoral thesis (2011). To sum up, the recent (re) discovery of Levýs thinking on translation has contributed to the methodological innovation of translation research.
\end{abstract}

Key words: Jiří Levý, reception, Spain, Latin America, translation research

\section{Úvodem}

Cílem článku je popsat recepci díla Jiř́ho Levého ve Španělsku a v Iberoamerice, konkrétně v Kolumbii a Brazílii. Česká, respektive československá teorie překladu není

1 Tato studie vznikla za podpory projektu Univerzity Karlovy Progres Q10, Jazyk v proměnách času, místa, kultury. 
v hispanofonní a lusofonní translatologii zcela neznámá, jak by se mohlo na první pohled zdát. V posledních letech dochází k renesanci zájmu o postuláty myslitelů slovanské provenience, české teorie překladu nevyjímaje (Králová 2013: 166). Nutno však dodat, že tato pozornost je často podnícena vzájemnou spoluprací a osobními kontakty mezi českými a zahraničními univerzitami. ${ }^{2}$

Levý formuloval své myšlenky ke konci padesátých let a dále je rozvíjel v průběhu šedesátých let dvacátého století. K jeho současníkům patřili francouzský teoretik G. Mounin (Les problèmes théoriques de la traduction, 1963), americký lingvista E. Nida (Toward a Science of Translating, 1964) či skotský lingvista J. C. Catford (A Linguistic Theory of Translation, 1965), jejichž díla, publikovaná v témže časovém intervalu jako práce Levého, položila základy dnešní západní translatologie.

Levého stěžejní dílo Umění překladu vyšlo poprvé v roce 1963 a dodnes se dočkalo třech reedicí, a to v letech 1983, 1998 a 2012. Kniha byla sepsána v češtině, tedy v minoritním jazyce, což je jeden z hlavních důvodů, proč stála poměrně dlouhou dobu stranou zájmu odborné veřejnosti. Mezinárodní translatologie se postupně seznámila s Levého bádáním o překladu prostřednictvím německého překladu, jenž byl publikován záhy po vydání českého originálu v roce 1969 a jehož se zhostil Walter Schamschula (Levý svůj text pro účely německého překladu upravil, především nahradil české př́iklady německými, tato předloha pochází z roku 1967). Na tomto místě pro zajímavost dodejme, že španělsky a portugalsky mluvící oblast, která je předmětem našeho článku, poznala Levého myšlenky právě prostřednictvím německé verze. Dále následoval překlad do ruštiny (1974), a poté do srbochorvatštiny, který vyšel o osm let později (1982). Teprve v roce 2011 se Umění přkladu dočkalo anglického překladu, bylo tedy konečně převedeno do dnešní lingvy franky, což ovšem neznamená, že by bylo Levého dílo (znovu) objeveno, spíše lze konstatovat, že je znovu čteno.

\section{Recepce díla Jiřího Levého ve Španělsku³}

Ve španělsky mluvícím světě se první zmínky o Levém objevují v 90. letech 20. století. Průkopníkem a hlavním propagátorem Levého uvažování o překladu je Miguel Ángel Vega Cernuda, který jako první odhalil a docenil kvalitu jeho tezí. Přední zakladatelské práce španělské translatologie totiž Levého jméno opomíjejí. ${ }^{4}$ Vegova monografie Textos clásicos de la teoría de la traducción (1994) věnovaná vývoji teorie překladu je tak prvním pokusem o představení Levého koncepcí ve španělském prostoru. Nicméně toto první uvedení nesplnilo očekávaný záměr autora a setkalo se pouze s vlahým ohlasem. Profesor

2 Zmiňme některé z nich: Univerzita v Alicante, Španělsko (Miguel Ángel Vega Cernuda, Juan Antonio Albaladejo Martínez, Elena Serrano Bertos), Univerzita ve Valladolidu, Španělsko (Antonio Bueno García, Fernando Navarro Domínguez), Univerzita v Antioquii, Kolumbie (Paula Andrea Montoya) či Univerzita v Santa Catarině, Kolumbie (Martha Lucía Pulido Correa).

3 Vzájemnou recepcí hispánských a českých teorií překladu se autorka detailně zabývá v následujícím článku: Vavroušová, Petra (2016) 'Al margen de la recepción recíproca de las teorías de la traducción checa e hispana', in Joanna Wilk-Racięska, Sabina Deditius, Anna Nowakowska-Głuszak (eds.) Relecturas y nuevos horizontes en los estudios hispánicos: cultura y traducción, Katowice: Wydawnictwo Uniwersytetu Śląskoegi, 136-146.

4 Valentín García Yebra (1983) nezmiňuje Levého vůbec a Amparo Hurtado Albir (2001) ho uvádí pouze v poznámce pod čarou, když vysvětluje Willisovu teorii, a dále pak v seznamu bibliografie. 
Vega, zaměřením germanista, logicky čerpá z německé verze a vyzdvihuje především Levého dvojí normu v překladu (Vega 1994: 325-327).

Zlom přichází v roce 2010 a od té doby se objevuje ve španělské translatologii mnoho prací, které se odvolávají na Levého koncepty a inspirují se jeho myšlenkami. ${ }^{5}$ Juan Miguel Zarandona (2010: 283) ve své recenzi na knížku Tradition versus Modernity. From the Classic Period of the Prague School to Translation Studies at the Beginning of the $21^{\text {st }}$ Century (2008) zdůrazňuje, že všechny příspěvky mají jednoho společného jmenovatele - odkaz na osobnost zakladatele české translatologie Jiřího Levého a jeho postuláty (především na překlad z funkčního hlediska). Čtenář recenze se dozvídá, že editorky Jana Králová a Zuzana Jettmarová poukazují na neznalost českých (Levý) a slovenských (Popovič) teorií překladu kvůli chybějícímu překladu do velkých světových jazyků a na mylné řazení Levého do Lipské školy. Zarandona (2010: 283) navíc také připomíná, že recenzovaná kniha byla vydána osmdesát let po založení Pražského lingvistického kroužku (1927), čtyřicet let po úmrtí Jiřího Levého (1967) a padesát let po vydání jeho díla České theorie překladu (1957) a nabádá čtenáře, aby se seznámili s jeho postuláty a přečetli si přinejmenším anglický zkrácený překlad Levého textu „The Process of Creation of a Work of Literature and its Reception“, jenž je součástí recenzované knihy. Ve stejném roce publikuje svůj článek také Zabalbeascoa (2010: 94), který o Levém mluví jako o současníkovi Nidy a ve své práci zmiňuje jeho funkční hierarchii v překladu.

V roce 2011 vychází publikace Posibilidades y límites de la comunicación intercultural, jejíž editorkou je Jana Králová. V této knize najdeme pět článků španělských translatologů, kteří se zaobírají či inspirují dílem Jiřího Levého. První dva články, „El caso Levý: Fenomenología de su recepción y valoración de sus aportaciones en el contexto de la traductología de la época“ od Miguela Ángela Vegy a „Jiří Levý: La teoría de la traducción y lingüística“ od Fernanda Navarra Domíngueze, se věnují recepci Levého díla ve Španělsku a hodnotí jeho přínos pro translatologii. Zbývající tři články citují Levého a aplikují jeho poznatky na svůj vlastní výzkum.

Vega (2011) se domnívá, že Levého průkopnické myšlenky se v teorii překladu objevily poměrně časně, již v padesátých a šedesátých letech 20. století, přesto zůstaly ve své době nedoceněny (byly psány česky, tudíž byl okruh čtenářů omezen). Teprve německý a ruský překlad Umění překladu a rovněž anglický článek „Translation as a Decision Process" (1966) zpř́ístupnily Levého koncepty světové translatologické komunitě. Vega (2011: 18-19) spatřuje Levého prrínos v následujících čtyřech oblastech:

- forma vs. význam: Vega oceňuje u Levého jeho odhodlání věnovat se ve svém klíčovém díle Umèní překladu literárnímu překladu a klást důraz, v porovnání se svými současníky, na formu;

- (anti-)iluzionistický překlad: V rámci estetických problémů v překladu Levý rozlišuje mezi překladem iluzionistickým, jenž by měl ve čtenáři vyvolávat iluzi, že čte originální dílo, a antiiluzionistickým, který naopak dává čtenáři najevo, že má před sebou překlad. Tyto dva protipóly Vega usouvztažňuje s Venutiho ortodoxním a heterodoxním překladem;

5 Julio-César Santoyo (2011: 1984) podotýká, že existuje bílé místo ve španělských dějinách překladu, pokud jde o slovanské teorie. Tuto situaci považuje za nepřípustnou a nabádá k jejich objevování a prostudování; nicméně konkrétně Levého nezmiňuje. 
- role překladu v národní literatuře: Vega zdůrazňuje v této souvislosti Levého názor, že originál, jenž je jedinečný, získává prostř̌ednictvím jednotlivých překladů do dalších jazyků na rozmanitosti;

- dějiny překladu: Vega představuje Levého prvotinu České theorie překladu, která poukazuje na jeho zájem o dějiny překladu - disciplínu, jež byla tehdy ještě v plenkách.

Navarro Domínguez (2011) studuje ve svém př́spěvku propojení mezi teorií překladu a jazykovědou a zařazuje Jiř́ho Levého do historického kontextu a usouvztažňuje jeho koncepty s některými pracemi francouzské provenience (Georges Mounin, Edmond Cary, Jean Paul Vinay nebo Jean Darbelnet). Připomíná, že španělská teorie překladu vděčí za seznámení s Levého dílem Vegovi, který odkazuje na Levého kapitolu „Dvojí norma v překladu" a vyzdvihuje především Levého reprodukční (věrný překlad) a uměleckou (volný překlad) normu a fakt, že by přeložené dílo mělo dosáhnout stejného účinku jako originál. Navarro (2011:22-24), jenž si je vědom, že jeho četba Levého díla je limitována neznalostí češtiny, podtrhuje následující tři aspekty v Levého tvorbě (tlumočí myšlenky, které př̀ednesla Králová na konferenci na Univerzitě v Alicante v dubnu roku 2009):

- překlad jako komunikační proces a tři fáze překladatelovy práce (pochopení, interpretace a přestylizování předlohy);

- překladatelovy pracovní postupy (překlad v pravém slova smyslu, substituce a transkripce) aplikované na překlad vlastních jmen;

- překlad jako rozhodovací proces (instrukce delimitativní, tj. repertoár prostředků, který má daný jazyk k dispozici, a instrukce selektivní, tj. výběr konkrétního jazykového prostředku).

Autorská dvojice Agustín Darias Marrero a Tenesor Sánchez Falcón (2011) hledá odpověd’ na Levého otázku-stat' „Bude teorie překladu užitečná překladatelům?““ (1971) a dochází $\mathrm{k}$ závěru, že ano, přinejmenším ve výuce překladu a tlumočení. Autoři totiž analyzují přetlumočení politických projevů na vzorku studentů tlumočnictví, tudíž aplikují Levého teoretické poznatky na didaktiku tlumočení (Darias, Sanchéz 2011:31-33). Vychází především $\mathrm{z}$ již zmiňovaného pojetí překladu jako rozhodovacího procesu a z domněnky, že překladatelé (tlumočníci) volí spiše obecnější výrazy, čímž dochází ke ztrátě specifických prvků na sémantické úrovni (Levý 1971). Neopomíjejí ani tři fáze překladatelovy práce.

Juan Antonio Albaladejo (2011) se ve svém př́spěvku zabývá výpůjčkami a při té příležitosti cituje Levého dvojí normu v překladu, konkrétně pak myšlenku, že překladatel má snahu vylepšovat originál a že kritik překladu musí být při hodnocení obezřetný (Albaladejo 2011: 44).

Posledním španělským autorem je Miguel Cuenca Drouhard (2011), který se ve svém článku „Překladovost y posun: ¿Causa o consecuencia?“ zamýšlí nad převodem Levého termínu „překladovost“ do španělštiny a přichází s neologismem „traductividad“ (Cuenca 2011: 82). ${ }^{6}$

Levý ve svém díle detailně pojednává o převodu jazykového materiálu (místního nářečí či cizího jazyka), který má funkci uměleckého prostředku. Zde lze najít styčný bod mezi českou a španělskou teorií překladu, nebot Juan Antonio Albaladejo se ve své

6 Jak je patrné z názvu článku, řeší i převod Popovičova termínu „posun“, pro který volí překladový ekvivalent „desviación“. 
dizertační práci, později vydané knižně jako La literatura marcada. Problemas de traducción y recepción ejemplificados a través del teatro popular vienés (2012), zabývá převodem příznakového jazyka na prŕkladu vídeňského lidového divadla. Albaladejo mnohokrát cituje Levého, nesouhlasí však s jeho tvrzením, že „není možné plné vystižení, nýbrž jen náznak“ (Levý 1983: 127-128), naopak se domnívá, že pro převod vnitrojazykových variant lze využít tzv. fonematického indexu, který vychází z teorie artikulačních univerzálií a který umožňuje překladateli převést příznakovost originálního textu do textu cílového.

Překladem reálií a prvků spjatých s danou kulturou se zabývá Nelson Cartagena (2013: 225) ve svém článku „Realia, cultura y traducción“, kde cituje Levého kapitolu věnovanou dobové a národní specifičnosti a jeho tezi, že u „místně a dobově zabarvených složek jde o to, zachovat nejen jejich význam, ale i hodnotu koloritní“ (Levý 1983: 119). Cartagena (2013: 225) dále usouvztažňuje Levého termíny s Reissovou a jejími „zeit- und ortsbezogene Determinanten“.

Santiago García Gaín (2014) se ve svém př́íspěvku věnuje kvalitě a recepci překladů Thomase Manna v americkém exilu. Odvolává se na Levého reprodukční normu a normu „uměleckosti“, včetně volného a věrného překladu (García Gaín 2014: 138).

Výše zmínění autoři jsou většinou germanisté, studovali tedy německou verzi Umění přkladu, která je pro španělskou translatologii klíčová, nebot díky ní poznala Levého koncepty (ostatní autoři se s jeho dílem seznámili bud' prostřednictvím španělsky či anglicky psaných prací českých teoretiků, kteří se zasazují o šíření Levého díla v zahraničí, nebo čerpali z českého originálu, nebot’ někteří ovládají češtinu).

Mezník přichází v roce 2013, kdy byla publikována španělská antologie Jiří Levý: una concepción (re)descubierta, která představuje výběr stěžejních prací Jiřího Levého, které přeložili Jana Králová a Miguel Cuenca Drouhard. Výběr roku 2013 pro vydání antologie není náhodný. Jedním z impulsů pro její vznik bylo vydání anglického překladu v roce 2011 a další motivací bylo uplynutí padesáti let od prvního vydání Umění prekladu. A s kterými texty se konkrétně může španělský čtenář seznámit? Autoři se rozhodli zařadit do svazku prolog a epilog Českých theorií překladu (1957), vybrané kapitoly z knihy Umění prekladu (1963) a z posmrtně vydaného díla Bude literární věda exaktní vědou? (1971), dále zkrácené verze textů Geneze a recepce literárního díla či Čapkovy překlady ve vývoji českého překladatelství a českého veršse a studii Bude teorie překladu užitečná překladatelìm. Cílem antologie je tedy obohatit současné debaty o metodologické diverzifikaci v současné translatologii a představit detailněji Levého teze týkající se překladu, např. překlad jako komunikační proces, přeložitelnost, překladovost, explicitace, intelektualizace, stylistická neutralizace, normy, role překladatele atd. Neméně významnou je také předmluva od Miguela Ángela Vegy, který Levého nazývá „minorizovaným“ myslitelem (nebot jeho myšlenky byly sepsány v minoritním jazyce, v češtině, a dlouho tak zůstaly utajeny zahraničnímu odbornému publiku) a jeho myšlení o překladu považuje za jedno z nejoriginálnějších (Vega 2013: 13). Elena Serrano Bertos (2014) ve své recenzi ${ }^{7}$ připomíná, že dílo Levého metodologicky vychází z Pražského lingvistického kroužku, tedy funkčního strukturalismu, a zdůrazňuje především dva Levého postuláty: historickou

Antologie byla také recenzována i českými autory: Vavroušová, Petra (2015) 'Reseña: Jiří Levý: una concepción (re)descubierta'. META, 3: 644-645. 
perspektivu překladu a překlad jako součást literárního systému; koncepty, jež lze považovat za předchůdce teorie polysystému.

\section{Recepce díla Jiřího Levého v Latinské Americe}

V následující části článku se přesuneme na americký kontinent, kde se zaměříme především na dvě země, a to portugalsky mluvící Brazílii a španělsky mluvící Kolumbii, v nichž jsme zaznamenali nejživější ohlas na Levého dílo.

\section{Brazílie a Levý v portugalštině}

Za „latinskoamerického Vegu“ lze považovat Filipeho Mendese Neckela, který ve své doktorské dizertační práci „Die literarische Übersetzung [dissertação]: apresentação da obra de Jiř́i Levý acompanhada de uma tradução comentada“ (2011)8, jež vznikla jako reakce na neexistující portugalské překlady Levého textů, představuje teorie tohoto českého filologa. Těžištěm práce je komentovaný překlad prvního dílu Umění překladu do portugalštiny, jehož předlohou byla německá verze. Neckel (2011: 14) přisuzuje německému překladu status originálu, nebot' Levý spolupracoval s W. Schamschulou a přizpůsobil text německému čtenáři. Vlastnímu překladu, který v dvojjazyčné německo-portugalské verzi tvoří součást příloh práce, předchází teoretické pojednání opírající se o myšlenky Jiřího Levého (deskriptivní teorie), Antoina Bermana (preskriptivní teorie, etický překlad) a Friedricha Schleiermachera. Neckel tedy umožnil portugalskému čtenáři první seznámení s Levého uvažováním o překladu (překlad jako rozhodovací proces, př̀eklad jako komunikační proces, instrukce selektivní a definiční, divergenční a konvergenční tendence, iluzionistický a anti-iluzionistický překlad, fáze překladatelovy práce, způsoby překladatelovy práce, překlad titulu literárního díla, překlad divadelního dialogu, volný a věrný překlad atd.), jež navazuje na poznatky pražského strukturalismu a ruského formalismu. V komentáři k překladu Neckel (2011: 66) vysvětluje, že se rozhodl pouze přeložit německé příklady, kterými Levý ilustruje mnohé teoretické jevy, a ne je substituovat portugalskou verzí (nutné poznámky překladatele a vysvětlení se nachází na konci překladu). Dále také komentuje, k jakým posunům došlo na jazykové rovině kvůli skutečnosti, že němčina a portugalština patří do různých jazykových systémů (Neckel 2011: 65).

O rok později vzniká jiný velký projekt, který zpř́istupnil další Levého texty poprvé v portugalštině, a tím je monotematické číslo časopisu Scientia Traductionis s názvem „(Re)doscobrindo Jiří Levý“, které vydala Universidade Federal de Santa Catarina. Číslo má bilingvní formát a jde vlastně o takovou antologii čtyř Levého statí a dále pak pěti článků inspirovaných jeho výroky. Všechny texty jsou publikovány zrcadlově v angličtině, němčině či španělštině s prŕslušným překladem do portugalštiny. Toto monotematické číslo sestává nejprve z úvodního slova obou editorů, kteří představují osobnost Jiř́ho Levého, poukazují na anglický překlad The Art of Translation (2011), který byl impulsem pro jejich počin, tedy pro převod některých studií do portugalštiny.

8 Dizertace vznikla pod vedením profesora Mauriho Furlana a byla obhájena na Universidade Federal de Santa Catalina v roce 2011. 
Článek, který otevírá celé vydání, nese název „Breve introdução ao pensamento tradutológico de Jiří Levý“ a Filipe Neckel (2012) v něm představuje základní koncepce českého myslitele, $v$ němž vidí zakladatele moderní teorie překladu, a vyzdvihuje jeho roli na poli dějin, kritiky a praxe překladu. Obsah článku vychází z teoretické části Neckelovy dizertace a je vlastně takovým shrnutím stěžejních myšlenek prvního dílu Umění překladu. I když se Levý zaobírá výhradně literárním překladem, Neckel (2012: 23) se domnívá, že jeho závěry jsou obecně platné, mohou posloužit jako metodologický nástroj pro analýzu překladu a položit základy teorie překladu.

Následuje Neckelův překlad třech fází překladatelovy práce "As três fases do trabalho tradutório: a apreensão, a interpretação e a transposição do modelo”. Portugalský čtenár má rovněž možnost seznámit se s Levého studiemi nejen ve výchozí anglické verzi („Will translation theory be of use to translators?" (1965), „Translation as a decision proces“ (1967) a „The process of creation of a work of literature and its reception - the creation of a translation“), ale také s jejich portugalskými protějšky („Terá a Teoria da Tradução Serventia aos Tradutores?", „A Tradução como um Processo de Tomada de Decisão“ a „O Processo de Criação de uma Obra Literária e sua Recepção - A Criação de uma Tradução“), v nichž nalezne Levého hlavní postuláty, tj. překlad jako komunikační proces či překlad jako rozhodovací proces.

Číslo pak uzavírají články zabývající se osobností Jiřího Levého či inspirované jeho tezemi. V první studii, v jazykovém páru angličtina a portugalština, Jettmarová (2011) vypovídá o překládání Umění překladu do cizích jazyků. Sérii článků psaných původně španělsky otevírá Vega (2011), následuje Králová (2011) a Navarro (2011). Upřesněme jen, že jsou to překlady článků publikovaných v roce 2011 v jiných odborných monografiích či sbornících, které byly komentovány výše.

Celé číslo nabízí nejrůznější interpretace Levého díla a autoři vybízejí čtenáře, aby si na základě četby Levého vytvořil vlastní názor.

\section{Kolumbie a Levý ve španělštině}

V roce 2016, tedy devadesát let od narození Jiř́ho Levého, se časopis Mutatis Mutandis rozhodl ve spolupráci s Univerzitou Karlovou v Praze a Univerzitami v Antioquii a Santa Catarině vydat monotematické číslo The Art of translation: Jiř́ Levý (1926-1967) y la otra historia de la Traductología ${ }^{9}$, které mapuje recepci českých teorií překladu v hispánském a lusofonním světě a zároveň předkládá mezinárodnímu publiku moderní studie, které z Levého koncepce překladu vycházejí. Vznik tohoto speciálního čísla je vlastně reakcí na již zmiňované překlady do angličtiny (2011), portugalštiny (2011) a španělštiny (2013) a rovněž na skutečnost, že Levého Umění překladu je považováno za referenční bod pro soudobou translatologii, byt to není autorovo první dílo.

Editorky čísla poukazují na empirický obrat v translatologii, který přispěl k obnovení zájmu o řadu aspektů, jež Levý ve svých dílech nastínil. Tyto myšlenky pak byly dále rozvíjeny badateli v oboru, mnozí se jimi inspirovali ve svém vlastním výzkumu a jsou

9 Montoya, Paula Andrea - Pulido C., Martha Lucía - Králová, Jana. The Art of translation: Jiří Levý (1926-1967) y la otra historia de la Traductología. Mutatis Mutandis, 2016, č. 2. [online]. [cit. 2. 8. 2017]. URL: <http://aprendeenlinea.udea.edu.co/revistas/index.php/mutatismutandis/issue /view/2436/showToc> 
tedy prrítomny v jednotlivých studiích. Úvodní studie autorské dvojice Králová a Svoboda (2016) popisuje dobu, ve které Levý koncipoval své teorie, a rovněž jeho současníky, zabývají se tím, jak je dílo Levého dnes hodnoceno a v neposlední řadě zmiňují Levého myšlenky tykající se historického kontextu a překladatelských norem. Na Levého koncepci překladu jako procesu navazuje většina článkủ tohoto čísla. Překladem literárních textů se zabývají Šotolová (2016), která se zamýšlí nad výběrem děl pro překlad a následné vydání, a Martino Alba (2016), jež zkoumá převody autobiografií z němčiny do španělštiny; Obdržálková (2016) se pak věnuje převodu neliterárních textů, Aurová (2016) se přiklání k př̀kladu jako rozhodovacímu procesu a Čermák (2016) uvažuje o aplikaci nových technologií na překlad. Cruz Romão (2016) se ve svém př́spěvku pokouší ukázat, jakou roli hrají při překládání poznámky překladatele, aby si čtenáŕ uvědomil komplexnost překladatelského procesu. Převodu autorského stylu se věnují Zehnalová (2016) a Molchan (2016), obě si jako př́klad zvolily Hrabala, prričemž Zehnalová zkoumá překlady do angličtiny a Molchan do ruštiny. $S$ převodem stylu autora pak logicky souvisí hodnocení překladu a právě oblast kritiky překladu si z učení Levého vybrala Nanci (2016). Kolmanová (2016) a Odrekhivska (2016) vycházejí ve svých anglicky psaných příspěvcích z Levého teze, jakou pozici zaujímá překlad $\mathrm{v}$ dané kultuře a jakou roli sehrává při tvorbě národní literatury, Kolmanová si jako vzorek vybrala českou a madarskou literaturu, Odrekhivska naopak zkoumá překlad dramatu na ukrajinském př́kladu. Problematikou překladu z/do ohrožených jazyků se ve svém článku zabývá Valeš (2016).

V témže roce vychází také dílo Sergia Bolañose Cuéllara Introducción a la traductología: autores, textos y comentarios (2016), jehož cílem je představit významné texty předních autorů moderní translatologie. Kniha má dvě části, první se soustředí na teorii překladu vycházející z lingvistiky a druhá se orientuje na teorii překladu zaměřenou na kulturu, literaturu a filozofii, kam spadá i Levý. Bolaños Cuéllar vychází z ruského překladu Umění překladu (1974) a v kapitole nazvané „Jiř́ Levý: La traducción literaria“ představuje základní teze Levého teorie (obecná a speciální teorie překladu, metody lingvistické a literárněvědné, překladatelský proces a estetické problémy překladu), které opatřuje vlastním kritickým komentářem (Bolaños 2016: 209-246). Neomezuje se však pouze na Umění prekeladu, ale vychází rovněž z článku „Translation as a Decision Process" a zamýšlí se nad Levého pojetím překladu jako rozhodovacího procesu. Levého řadí mezi pionýry translatologie orientované na kulturní převod a literární překlad, po boku Waltera Benjamina a Vladimira Nabokova. V závěru se Bolaños (2016: 245) pozastavuje nad tím, že Levého texty nebyly přeloženy do španělštiny (sic!).

\section{Závěrem}

Současný empirický obrat v translatologickém světě (znovu)objevuje koncepty, které ještě donedávna zůstávaly stranou pozornosti mezinárodního odborného publika, nebot’ mnohé z těchto myšlenek byly sepsány v jazyce minoritním, což je i případ české teorie překladu a jejího zakladatele. ${ }^{10}$ Tato skutečnost přispívá $\mathrm{k}$ metodologické renovaci na

10 Je záhodno zmínit, že hlavními propagátorkami Levého díla v zahraničí jsou Jana Králová a Zuzana Jettmarová (obě vyučující Ústavu translatologie FF UK), které publikovaly celou řadu článků v zahra- 
poli translatologie, nebot’ se do popředí dostávají doposud marginalizované, či dokonce marginální koncepce.

Dnes jsou již koncepty Jiřího Levého přístupné široké odborné veřejnosti v nejrůznějších jazykových verzích, a nejen že jsou čteny se zájmem, ale jsou hojně využívány při nejrůznějších výzkumech a podněcují tak další bádání v translatologii.

Recepce díla Jiřího Levého v hispanofonním a lusofonním světě není tak skrovná, jak by se mohla na první pohled zdát (Králová 2013: 169). Největší boom nastal především po roce 2011, kdy bylo Levého stěžejní dílo Umění překladu přeloženo do angličtiny a zároveň do portugalštiny, o dva roky později také do španělštiny, byt do obou zmíněných románských jazyků pouze částečně (vybrané reprezentativní pasáže).

Sám Levý (1971: 156) specifikoval důležitost překladu těmito slovy: „z hlediska každé národní literatury je překlad rozlišujícím činitelem, nebot přidává k rodným, autochtonním stylům a zpo̊sobům myšlení impulzy odvozené [...], a tak přispívá k vnitřní diferenciaci jednotlivé národní literatury“, a my jen můžeme dodat, že překlady textů Levého hrají svou roli při šíření myšlenek tohoto českého velikána na poli mezinárodní translatologie a přispívají tak k metodologické inovaci a studiu dosud neobjevených koncepcí, které zůstaly hispanofonnímu a lusofonnímu světu dlouho utajeny pouze kvůli jazykové bariéře.

Přestože Levý své koncepce definoval před více než padesáti lety, dosud neztratily svoji platnost. Znalost jeho teoretických poznatků může přispět k vzájemné výměně na poli translatologie a k hledání styčných bodů mezi českou a hispano- či lusofonní teorií překladu (např. cenzura, nepř́mý překlad či převod vnitrojazykových variant).

\section{BIBLIOGRAFIE}

Albaladejo Martínez, Juan Antonio (2011) 'El préstamo entre transparencia y opacidad: ¿Medio o impedimento en la comunicación intercultural?', in Jana Králová (ed.) Posibilidades y límites de la comunicación intercultural, Praha: Karolinum, 41-50.

- (2012) La literatura marcada. Problemas de traducción y recepción ejemplificados a través del teatro popular vienés. Monografías de la revista Herméneus, Soria: Vertere.

Aurová, Miroslava (2016) 'La perspectiva funcional de la oración (PFO) en la traducción: paradigmas e instrucciones selectivas', Mutatis Mutandis (2): 383-400.

Bolaños Cuéllar, Sergio (2016) Introduccióna la traductología: autores, textos y comentarios, Bogotá: Editorial Universidad Nacional de Colombia - Editorial Universidad del Rosario.

Cartagena, Nelson (2013) 'Realia, cultura y traducción', in Antonio Bueno García, Miguel Ángel Vega Cernuda (eds.) Traducción y humanismo, Bruxelles: Editions du Hasard, 213-228.

Čermák, Petr (2016) 'La traducción como proceso de decisiones: su reflejo en los corpus paralelo', Mutatis Mutandis (2): 224-246.

Cruz Romão, Tito Lívio (2016) 'Considerações sobre a tradução brasileira de Die Idee des Guten zwischen Plato und Aristoteles de Hans-Georg Gadamer à luz de preceitos teóricos de Jiř́ Levý, Mutatis Mutandis (2): $328-347$.

Cuenca Drouhard, Miguel José (2011) 'Překladovost y posun: ¿Causa o consecuencia?', in Jana Králová (ed.) Posibilidades y límites de la comunicación intercultural, Praha: Karolinum, 79-83.

ničních periodicích. Z mladší generace zmiňme např. dizertační práce či články Jaroslava Špirka, Miguela Cuency nebo Petry Vavroušové. 
Darias Marrero, Agustín, Sánchez Falcón, Tenesor (2011) 'Interpretación en discursos políticos: una experiencia didáctica, in Jana Králová (ed.) Posibilidades y límites de la comunicación intercultural, Praha: Karolinum, 31-40.

Furlan, Mauri, Althoff, Gustavo (2012) '(Re)descobrindo Jiří Levý, Scientia Traductionis (11): https:// impactum.uc.pt/es/content/revista?tid=30429\&id=30429 (access: 2.8 . 2017).

García Gaín, Santiago (2014) 'Acogida de la traducción de la obra de Tomas Mann en su exilio estadounidense', Herméneus (16): 127-142.

García Yebra, Valentín (1983) Teoría y Práctica de la traducción, Madrid: Gredos.

Hurtado Albir, Amparo (2001) Traducción y Traductología, Madrid: Cátedra.

Jettmarová, Zuzana (2011) 'Translating Jiří Levýs Art of Translation for an Internatinal Readership', in Jana Králová (ed.) Posibilidades y límites de la comunicación intercultural, Praha: Karolinum, 51-60.

Kolmanová, Simona (2016) 'Notes on the theory and practice of translation in Central-Europe: The confrontation of translation approaches in the Czech and Hungarian translations of The Raven by Edgar Alan Poe and its position in the Czech and Hungarian literary context', Mutatis Mutandis (2): 401-417.

Králová, Jana (2011) 'La multifacética realidad del lenguaje’, Lorenzo Hervás (20): 299-310.

(2013) 'La recepción de la obra de Jiří Levý en los países hispanos y lusófonos', in Slavomír Míca, Miroslav Valeš (eds.) Diversidad Lingüística del Español, Liberec: Universidad Técnica de Liberec, 161-169.

Králová, Jana, Miguel José Cuenca Drouhard (2013) Jiř́ Levý: una concepción (re)descubierta, Soria: Vertere. Monográficos de la revista Herméneus 15.

Králová, Jana, Svoboda, Tomáš (2016) 'Jiř̌́ Levý en el contexto de la investigación de la época y en la actualidad', Mutatis Mutandis (2): 205-223.

Levý, Jiří (1957) České theorie prekladu. Praha: SNKLHU.

(1963) Umění prekladu. Praha: Československý spisovatel.

(1969) Die literarische Übersetzung: Theorie einer Kunstgattung, Frankfurt am Main/Bonn: Athenäum Verlag.

- (1971) Bude literární věda exaktní vědou? Praha: Československý spisovatel.

(1983) Umèní překladu. Praha: Ivo Železný.

(2011) The Art of Translation, Amsterdam: John Benjamins Publishing Company.

Martino Alba, Pilar (2016) 'La reivindicación de la autobiografía de artista como género literario, basada en los problemas estéticos del Arte de la Traducción de Jiř́ Levý, Mutatis Mutandis (2), 363-382.

Molchan, Maria (2016) 'Metodología para el análisis traductológico de grandes corpus de textos literarios', Mutatis Mutandis (2), 267-285.

Montoya, Paula Andrea, Pulido C., Martha Lucía, Králová, Jana (eds.) (2016) ‘The Art of translation: Jiří Levý (1926-1967) y la otra historia de la Traductología', Mutatis Mutandis (2): http://aprendeenlinea .udea.edu.co/revistas/index.php/mutatismutandis/issue/view/2436/showToc (access: 2. 8. 2017).

Nanci, Giovanna (2016) 'La critica della traduzione di Jiř́ Levý in relazione al modello analitico di Lance Hewson', Mutatis Mutandis (2): 286-305.

Navarro Domínguez, Fernando (2011) 'Jiř́i Levý: La teoría de la traducción y linguística', in Jana Králová (ed.) Posibilidades y límites de la comunicación intercultural, Praha: Karolinum, 21-30.

Neckel, Filipe (2012) ‘Breve introdução ao pensamento tradutológico de Jiř́ Levý, Scientia Traductionis (11): 10-23.

Obdržálková, Vanda (2016) 'Translation as a decision-making process: an application of the model proposed by Jiří Levý to translation into a non-mother tongue', Mutatis Mutandis (2): 306-327.

Odrekhivska, Iryna (2016) 'Anti-illusionist Trend in Drama Translation: Re-framing Jiří Levýs Concept', Mutatis Mutandis (2), 247-266.

Santoyo, Julio-César (2011) 'Iberian translation history: what we know and do not know', in Harald Kittel (ed.) Übersetzung, Translation, Traduction, Berlin, Boston: Walter de Gruyter, 1982-1984.

Serrano Bertos, Elena (2014) 'Jiř́ Levý: una concepción (re)descubierta', Linguistica Pragensia (1): 84-87.

Šotolová, Jovanka (2016) 'La littérature française à travers ses traductions tchèques au cours des 25 dernières années', Mutatis Mutandis (2): 445-463.

Valeš, Miroslav (2016) 'A Fala: dimensión sociolingüística en las traducciones a una lengua minorizada', Mutatis Mutandis (2): 348-362. 
Vavroušová, Petra (2015) ‘Reseña: Jiří Levý: una concepción (re)descubierta’, META (3): 644-645.

(2016) 'Al margen de la recepción recíproca de las teorías de la traducción checa e hispana', in Joanna Wilk-Racięska, Sabina Deditius, Anna Nowakowska-Głuszak (eds.) Relecturas y nuevos horizontes en los estudios hispánicos: cultura y traducción, Katowice: Wydawnictwo Uniwersytetu Śląskoegi, 136-146.

Vega Cernuda, Miguel Ángel (1994) Textos clásicos de la teoría de la traducción. Madrid: Cátedra.

- (2011) 'El caso Levý: Fenomenología de su recepción y valoración de sus aportaciones en el contexto de la traductología de la época', in Jana Králová (ed.) Posibilidades y límites de la comunicación intercultural, Praha: Karolinum, 11-20.

— (2013) 'Prólogo', in Jana Králová, Miguel José Cuenca Drouhard (eds.) Jiří Levý: Una concepción (re)- descubierta, Soria: Vertere. Monográficos de la revista Herméneus 15, 13-18.

Zabalbeascoa, Patrick (2010) 'A Map and a Compass for Navigating through Translation', in Mïcaela Muñoz-Calvo, Carmen Buesa Gómez (eds.) Translation and Cultural Identity: Selected Essays on Translation and Cross-cultural Communication, Newcastle: Cambridge Scholars Publishing, 83-106.

Zarandona, Juan Miguel (2010) 'Tradition versus Modernity. From the Classic Period of the Prague School to Translation Studies at the Beginning of the 21st Century', Herméneus (12): 283.

Zehnalová, Jitka (2016) 'Literary Style and Its Transfer in Translation: Bohumil Hrabal in English', Mutatis Mutandis (2): 418-444.

\section{RESUMEN}

El presente artículo retrata la recepción contemporánea del pensamiento del teórico de la traducción checo Jiří Levý en España y en Iberoamérica (en concreto en Colombia y Brasil). Sus ideas formuladas en los años cincuenta del siglo XX siguen teniendo su validez hasta nuestros días; sin embargo, el hecho de que redactó sus textos en una lengua minoritaria hizo que el público académico mundial no pudo durante mucho tiempo conocer sus conceptos tan innovadores que giran acerca de los temas entre los que destacan la traducción como proceso de decisiones, la traducción como proceso comunicativo o la perspectiva histórica de la traducción. Las ideas del filólogo checo han sido reveladas a nivel internacional a partir del año 2011 cuando se publica la traducción inglesa de su obra principal El arte de la traducción (1963); no obstante, el mundo traductológico hispano y lusófono llegó a conocer las reflexiones del pensador checo un poco antes mediante la traducción alemana (1969). Es sorprendente que la recepción de su trabajo en la zona española y portuguesa no sea tan escasa como podría parecer y que Levý tiene sus admiradores que se esfuerzan por divulgar su trabajo en sus respectivos ámbitos (Vega en castellano y Neckel en portugués). Además, las revistas latinoamericanas de traducción publicaron números monotemáticos que elogian y aprecian la obra de este gran teórico checo (Brasil, Scientia Traductionis, 2012 y Colombia, Mutatis Mutandis, 2016). Asimismo, de mucha importancia es tanto la antología española Jiř́ Levý: una concepción (re)descubierta (2013), compuesta de sus textos más representativos escogidos y traducidos por Jana Králová y Miguel Cuenca como la traducción comentada al portugués de la primera parte de su obra clave elaborada por Filipe Neckel que forma parte de su tesis doctoral (2011). Entonces, el recién (re)descubrimiento de la opinión de Levý acerca de la traducción contribuye a la innovación metodológica en la comunidad científica, y además, sirve también para buscar y crear puntos tangentes entre la teoría de la traducción checa e hispana o lusofóna (por ejemplo, censura y control de la producción literaria, traducciones mediadas o trasvase de las variedades intralingüísticas).

PhDr. Mgr. Petra Mračková Vavroušová, Ph.D. Ústav translatologie, Filozofická fakulta Univerzity Karlovy, Praha Petra.Vavrousova@ff.cuni.cz 